\title{
Occurrence of Infestation with the Isopod, Alitropus Typus M. Edwards (Crustacea: Flabellifera: Aegidae) on Commercially Important Freshwater Fishes of Kerala, India
}

\section{Kummari Suresh}

Kerala University of Fisheries and Ocean Studies

Shalini Gopi

Kerala University of Fisheries and Ocean Studies

C.G. Rakesh

Kerala University of Fisheries and Ocean Studies

Gijo Ittoop

Kerala University of Fisheries and Ocean Studies

Devika Pillai ( $\nabla$ devikamanoj.pillai@gmail.com)

Kerala University of Fisheries and Ocean Studies.

\section{Research Article}

Keywords: Alitropus typus, Isopod, Infestation, Histopathology, Gill damage

Posted Date: December 8th, 2021

DOI: https://doi.org/10.21203/rs.3.rs-1123976/v1

License: (c) (1) This work is licensed under a Creative Commons Attribution 4.0 International License.

Read Full License

Version of Record: A version of this preprint was published at Journal of Parasitic Diseases on April 24th, 2022. See the published version at https://doi.org/10.1007/s12639-022-01488-0. 


\section{Abstract}

Rapidly rising temperatures and increasing organic load in the inland and coastal waters has led to a significant increase in parasite population. The isopod Alitropus typus infestation on fish in these waters have become more frequent, causing mortalities in both wild and cultured fishes. The present study was aimed to investigate the infestation on different fish hosts, mean intensity, prevalence, environmental influences on the parasite abundance and the histopathological changes it causes in the host. A total of 219 isopod specimens were collected from 149 infested fishes in two districts of Kerala, India. Among the different fish hosts, Channa striata was found to be the most susceptible, followed by Catla catla, Cyprinus carpio, and Wallago attu, with $81 \%, 10 \%, 7 \%$, and $2 \%$ occurrence, respectively. The prevalence and mean intensity of infestation were found to be $69.8 \%, 44.4 \%, 68.2 \%, 62.5 \%$ and $1.33,4.25,1.26,1.80$ in C. striata, W. attu, C. catla, and C. carpio, respectively. The parasite abundance was directly influenced by temperature and rainfall patterns. The histopathology of affected gill tissues showed epithelial lifting, rupture of secondary gill filaments, vacuole formation and hemocytic infiltration. The findings indicated that the isopod parasite, $A$. typus had a negative impact on fish health and appearance, causing economic losses to the small scale farmers/fishermen. This is the first reported record of the infestation of isopod parasite, A. typus on the Indian major carp C. catla and C. carpio from India.

\section{Introduction}

Parasitic infestations are a major cause of concern particularly in extensive and semi-intensive fish culture facilities. Among the parasitic infestations, ectoparasitic infectious crustaceans are seriously affecting the freshwater fishes all over the world (Mishra et al. 2017). Parasites survive in a dynamic equilibrium with their hosts and derive energy for their survival from them, which involves an effect on the behavior, health and distribution of hosts (Rameshkumar and Ravichandran 2010; Carrasson and Cribb 2014; Baillie et al. 2019).

A. typus, an isopod parasite belonging to the order Isopoda and family Aegidae, is a common crustacean ectoparasite affecting many freshwater fishes and causes significant economic losses to the aquaculture industry (Bunkley-William et al. 2006). Morphologically, A. typus are small in size, ranging from 0.5 to 3.0 $\mathrm{cm}$ in length, with a distinctive dorsoventrally flattened body, and are found in tropical and subtropical regions of Thailand, Australia, Indonesia, India, Sri Lanka, Malaysia, Borneo, and Sumatra (Fernando and Hanek 1973; Nair 1980; Bruce 1983; Ho and Tonguthai 1992; Lopez 2001; Lester and Hayward 2006; Lester 2005; Montelli and Lewis 2008; Ravichandran et al. 2009; Peninal et al. 2014). It has a holoxenic life cycle, facultatively survive in freshwater bodies and can infect wide range of fishes which includes Macropodus cupanus, Tilapia mossambica, Anabas testudineus, Puntius sarana, Etroplus suratensis, E. maculatus, Rasbora daniconius, Channa orientalis, and Mystus gulio (Nair et al. 1981; Kabata 1985; Chinabut 2002; Rajkumar et al. 2005a). These are sanguinivorous parasites that attach to exposed body parts such as mouth or gill chamber, nostrils or occasionally in self-made pockets in the flesh of their hosts (Lester 2005; Ravichandran et al. 2007; Kerry et al. 2017). The parasite attached to the gill occupies the entire branchial chamber of the host and exerts pressure on the gill surface, which ends up in gill 
filament erosion and thickening, thus reducing the respiratory efficacy (Rajkumar et al. 2005a). Due to the blood feeding nature, parasites weaken the fish by causing anaemia, as reported by Ghani (2003) and Rameshkumar and Ravichandran (2010). A weak fish is more vulnerable to a variety of fatal diseases. Moreover, the tissues damaged by the parasite are prone to secondary infection by bacteria and fungi (Lima et al. 2013; Eiras and Castro 2016; Watchariya and Songsuk 2020). A. typus infestations are reported to be common during the rainy season and can result in $50-100 \%$ mortality of fish (host) within 2-7 days of initial infestation. The severity of the infestation can be extremely high, and 15-20 parasites can kill a 2-3-inch tilapia in 5-6 hours (Chinabut 2002).

The reports of parasitic infestation by A. typus in the freshwater fish farms from different districts of Kerala, India, by aqua farmers have become more frequent. The present study was initiated to understand the prevalence and parasitic adaptation of the species in commercially important cultured freshwater fishes and the histopathological changes caused in the site of attachment.

\section{Materials And Methods \\ 2.1. Sample collection}

Samples of fish with parasites were collected from capture and culture facilities of Ernakulum $\left(9^{\circ} 58^{\prime} 48.00^{\prime \prime} \mathrm{N}, 76^{\circ} 16^{\prime} 48.00^{\prime \prime} \mathrm{E}\right)$ and Thrissur $\left(1^{\circ} 31^{\prime} 12.00^{\prime \prime} \mathrm{N}, 76^{\circ} 12^{\prime} 36.00^{\prime \prime} \mathrm{E}\right)$ districts of Kerala, India every month from January 2019 to June 2019. During each sampling, the fishes collected by each netting operation were scanned for infestation. The number and species of fishes infested and the total number of fishes examined were recorded in the field itself. The prevalence and mean intensity of parasites were calculated according to Bush et al. (1997) and Margolis et al. (1982) as follows.

Prevalence $=$ number of individuals of a host species infested with a particular parasite $/$ number of that particular species examined/caught.

Mean intensity = total number of parasites in a sample of infected host species / number of infected individuals of the host species in the sample.

The fishes infested with the parasite were immediately transported to laboratory of the Department of Aquatic Animal Health Management Kerala University of Fisheries and Ocean studies, Kerala, India for gross examination and further studies.

\subsection{Gross Examination}

The fish samples were anesthetized using clove oil (30-40 mg/L) for gross examination. The attachment sites of parasite, orientation on the host, and the number of parasites found in each fish were recorded. The skin, mouth, nasal cavities, branchial cavities and opercular chambers of each fish were examined as described in previous reports by Pillai (1954), Veerapan and Ravichandran (2000) and Martin and Davis 
(2001). The skin scrapings and gills from the affected fishes were examined under compound microscope (Olympus, Japan). The position, colour and shape of all the internal organs like liver, muscle, heart, kidney, spleen, and gonads were observed post mortem.

The parasites were carefully removed with forceps and were fixed in 10\% formalin and $70 \%$ ethanol separately for further studies. The mouth parts and appendages of the parasite were dissected and temporary mounts were prepared for parasitic identification using the taxonomic key of Aneesh et al. (2016b) and also to understand adaptation for attachment and feeding. Drawings of appendages were made using Camera Lucida (Olympus, Japan) attached to microscope. Representative isopod parasite specimens were deposited at the AAHM repository, KUFOS, Kerala, India.

\subsection{Histopathology}

The histology of gill tissues was done to understand the tissue damage caused by $A$. typus. The gills samples were fixed in neutral buffered formalin for a minimum period of $24 \mathrm{~h}$. The fixed samples were dehydrated and cleared using series of ethanol and xylene concentrations, then impregnated with paraffin wax using an automatic benchtop tissue processor and tissue embedder (Leica, Germany), following standard procedures. $5 \mu \mathrm{m}$ thick sections prepared using a semi-automatic microtome (Leica, Germany) were stained with hematoxylin and eosin (Roberts 2012), followed by mounting with DPX.

\subsection{Influence of environmental temperature and rainfall on parasite abundance}

Data of average monthly temperature and rainfall pattern of the study period were collected from the India Meteorological Department, Kerala (http://www.imdtvm.gov.in) and it was compared with parasite prevalence to understand the influence of environmental temperature and rainfall pattern on parasite abundance in selected areas.

\section{Results}

\subsection{Gross examination}

A total number of 219 fishes were examined in the study; among this, $C$. striata, $W$. attu, C. carpio and $C$. catla were the susceptible host species. Other fishes caught along with the above mentioned species were unaffected. It was interesting to note that among the Indian major carps, L. rohita and C. mrigala were unaffected. The parasites were positioned on the skin and gills, in the buccal cavity and opercular cavity (Fig. 1). Excess mucus production, abnormal swimming behaviour, scale loss, wounds and reddening of the attached areas were observed in infested fishes. The fishes appeared weak and emaciated compared to non-infested fishes and had pale gills. In the fishes infested with parasite on the gills, there was significant damage to the gills filaments. Other internal organs examined were found normal. Figure 2 shows the percentage of $A$. typus infested host species among the total infested fishes. Maximum infestation was found in C. striata (81\%) and minimum in W. attu (2\%). 
The parasites were found to attach itself to the gills and opercular regions of the fish, and skin surface through the use of hooked terminal segments (dactylus) of its pereopods to feed on blood and mucus. Those found on the fish skin had long dactylus with a sharp hook which had a claw like appearance, whereas those on the gills had shorter dactylus with a less prominent hooked appearance.

The isopod specimens collected were from 149 infested fishes. The number of parasites found in each fish ranged from one to three, on an average and up to a maximum of five in $W$. attu. The parasites were found alive even $24-48 \mathrm{~h}$ after the death of the host. More than $50 \%$ of the parasites were found on the gills of infested fishes. It was found to be clinging strongly on to skin and gills of the host with its hook like dactylus of the pereopods (Fig. 3).

\subsection{Morphological features of A. typus}

The body of the parasite was comparatively long, obovate, and the antero-median part of the cephalon was shaped like a triangle. The eyes were big and brown-black in colour. The size of the parasite varied from 17 to $24 \mathrm{~mm}$ in length and 8.5 to $12.5 \mathrm{~mm}$ in breadth. There were seven pereonites with seven pairs of pereopods. In the case of females, the pereonites 5-7 were distinctly larger than pereonites 1-4, with relatively small coxae. The first pleonite was strongly arched and was the smallest. It was not concealed by pereonite 7 , thus forming a "waist" in dorsal view. Posterolateral margins of pleonite 4 were having setae that concealed lateral margins of pleonite 5 . Pleotelson was about $7.5 \mathrm{~mm}$ long. Antennules were with 3 segmented peduncles armed with aesthetascs. Antennae were having 5 segmented peduncles. Frontal lamina was minute, oblong and wedged, Y-shaped clypeus, which was not in direct contact with bases of antennae. Labrum was broad strongly arched and covered with scale like cuticular ornaments; lateral edges heavily sclerotised. Mandible with sharply pointed incisor bearing reduced molar process covered with scale like cuticular ornaments. Mandibular palp about as long as mandible; terminal segment armed with row of 15 serrate spines. Maxillulae slender, tipped with one large, curved spine and 4 smaller straight spines. Maxillae larger than maxillulae, lateral lobe armed with 3 hooked spines and medial lobe with a small cylindrical process covered with microtrich crescents. Pereiopods IV-VII ambulatory; distal ends of merus and carpus armed with simple setae, forked spines, and blunt spines with sub-terminal flagellum; medial surface of ischium, merus, carpus and propodus bearing various numbers of blunt spines and sub-terminal flagellum. The male was smaller than female with second pleopod having an incompletely developed copulatory stylet at the inner margin of endopod. Based on the taxonomic key of Aneesh et al. (2016b), the species was concluded to be A. typus based on morphological features.

\subsection{Histopathology Of Gills}

Histologically, severe changes were noticed in parasite infested gill tissues of $C$. striata. The histological changes in the gills of parasite infested $C$. striata include rupture of the primary and secondary lamellae, haemocytic infiltration, epithelial lifting and vacuole formation (Fig. 4). 


\subsection{Intensity Of Infestation And Prevalence}

The average mean intensity of infestation per fish was 1.46 parasites, but in the case of $W$. attu, more than five isopods were found on one fish during the monsoon period. The mean parasite intensity on $W$. attu was 4.25 , followed by $C$. striata, $C$. catla, and $C$. carpio at $1.33,1.27$, and 1.80 per infected fish, respectively (Fig. 5). Similarly, the prevalence of infestation was found to be $69.8 \%, 44.4 \%, 68.2 \%$, and $62.5 \%$ in C. striata, W. attu, C. catla, and C. carpio, respectively (Fig. 5).

\subsection{Month Wise Variation In Infestation}

Infested fishes were available throughout the study period. The pattern of infestation on from January to June is expressed in Fig. 6. The percentage of infestation was found to be highest in April when most of the fishes examined were infested. In the month of June, the number of fishes with parasite among the examined fishes was minimum.

\subsection{Influence of temperature and rainfall on isopod parasite A. typus}

Temperature and rainfall data were collected over the period of the six-month study. The parasite abundance increased with increase in temperature from January to April and then reduced with the onset of monsoon, when the temperature decreased (Fig. 7). During the period of study, there was a slight increase in rainfall from January up to April, after which, with the onset of monsoon, there was an exponential increase of the same as shown in Fig. 7. It can be seen that although the parasite abundance increased along with slight increase in rainfall from January to April, it decreased from May onwards, with the onset of monsoon when the environmental temperature dropped. This shows that temperature is the major factor that affect parasitic abundance.

\section{Discussion}

Parasitic diseases in fishes seriously limit aquaculture production and its economic viability in waters of tropical and subtropical areas, both in wild and culture systems (Kensley 2001). Several facultative and obligatory parasites belonging to order Isopoda, family Aegidae, Class Maxillopoda are capable of tremendous damage leading to growth retardation, emaciation, anemia and often death of the infested fish (Carrasson and Cribb 2014). Although parasite infestation may not result in immediate death, the repulsive appearance of the fish infested with parasites will cause significant economic losses by reducing its market value (Lima et al. 2013; Eiras and Castro, 2016). A. typus is a notorious and active ectoparasite which infects fresh and brackish water fish fauna (Ravichandran et al. 2009). In the present study, A. typus was found attached to the skin, gills and opercular chambers of $C$. striata, C. catla, $C$. carpio and $W$. attu caught from capture and culture facilities of the fresh and brackish waters along the southwest coast of India. Although it is reported to infest fishes such as Anabas testudineus, Puntius sarana, Channa orientalis, Lebistes reticulates, Tilapia mossambica, and Macropodus cupanus (Nair et 
al. 1983), in the present study, infestation was not found in any of these fish species and other carps caught along with the four species of fish mentioned above.

According to Baillie et al. (2019), parasite attachment structure and area of attachment are critical traits in host exploitation and survival. It was observed in the present study that the parasite was having long and slender body tapering towards the ends and the efficient contour of the body offers minimal resistance to the water flow. The dactylus of the pereopod were modified with sharp edges to facilitate attachment. It is reported that the isopod, when found in the gill cavity, can impair respiration by causing gill atrophy due to the pressure it exerts on the gills, and in the mouth cavity, it can impede normal feeding by causing changes in the oral structures of the host like wasting of tongue (Kabata, 1985; Lester, 2005; Ravichandran et al. 2007; Kerry et al. 2017). Gill attached parasites feeds on blood from epithelial tissues, causing a reduction in the total erythrocyte count and hemoglobin content that result in anemia (Nair and Nair 1983). Hematological studies were not done in the present study. However, the infested fishes appeared to be very weak and emaciated with pale gills, thus showing symptoms of anaemia. It was also found that the favourite site of the parasite for attachment and feeding was the gills, as most of the parasites were seen within the gill chamber of the infested fishes regardless of the species of the host. Frequent shifts in position as the parasite feeds on the host results in serious wounds that make the host more vulnerable to secondary disease-causing agents (Lima et al. 2013; Eiras and Castro 2016; Watchariya and Songsuk 2020). In the present study too, there were wounds on the body of the infested fishes, which may be because of this behaviour of the parasites.

The histopathological studies of the gills showed rupture of the lamellae, epithelial uplifting, vacuolization and infiltration of blood cells. The pressure exerted by the parasite on the gills and attachment of parasites with their hooked pereopods may be the reasons for the observed pathological changes including rupture of the lamellae. In addition, haemocytic infiltration is primarily caused by increased blood flow as a host defense mechanism. The present observation correlates with the results of histopathological studies done by Ravichandran et al. (2007) and Mohammadi et al. (2012) on the gills of Joryma tardoor, Astronotus ocellatus and Symphysodon spp infested with isopods. Lifting of the respiratory epithelium is one of the earliest injuries found in fish and it is characterized by the displacement of the lining epithelium of the secondary lamellae which leads to edema (Santos et al. 2014).

The average mean intensity and prevalence have a significant impact on host survival. According to Aydodgu et al (2015) water temperature, water pollution, parasite biology, the hormonal status, immune response, migration and feeding habits of the host and the availability of intermediate host might influence the parasite intensity and prevalence. The mean intensity of infestation in the present study was highest in $W$. attu and lowest in C. carpio. One of the important factors determining the mean intensity and prevalence of parasites infesting each fish is the surface area of the gills and opercular chamber (Ravichandran et al. 2009). The surface area of the gills in $W$. attu is greater than in other fishes, which is most likely the cause of the high mean intensity. More than three parasites were frequently found on the gills of $W$. attu, whereas only one to two parasites were found on the gills of $C$. striata. A low 
mean intensity of infestation in fish population appears to pose no danger, but the whole population can get infested within no time, especially in semi intensive and intensive culture facilities. In the present study, C. striata had the highest prevalence of infestation and $W$. attu had the lowest (Fig. 5). Although low prevalence of infestation does not appear to impact the economic viability, it alters fish behavior, anatomy and morphology (Sasal 2005; Ravi and Rajkumar 2007) and also, makes the fishes more prone or susceptible to secondary infections.

Water temperature is a key variable of the aquatic ecosystem influencing many aspects in aquatic organisms and pathogen existence in terms of growth, host susceptibility, disease transmission, increase in pathogen development and survival rate (Mallick and Panigrahi et al. 2018). There exists a relation between the environmental parameters and outbreak of parasitic diseases, although it is not always direct (Short et al. 2017). Many studies have found temperature to be one of the most important variables controlling the elevational distribution of parasites (Oommen and Shanker 2005; Meik and Lawing 2008; Marcohliese 2016). It is also reported that the seasonal distribution of helminth parasites is influenced by temperature (Hanzelova and Zintan, 1985). In the current study a direct correlation was found between temperature and the prevalence of $A$. typus (Fig. 7). There are several reports that supports the finding where rising temperatures accelerate the replication rate and virulence of parasites affecting the economic and social viability of aquaculture (Marcohliese 2008; Collins et al. 2020). The decrease in the abundance of the parasites with the onset of monsoon in the present study, may be attributed to reduced water temperature due to heavy rainfall.

There are no specific or effective and environmentally safe chemotherapeutic measures available to control this parasite other than manual removal of parasites and management through optimal implementation of management practices based on good water quality, nutrition, sanitation, and quarantine. For pond treatment, a chemical treatment with trichlorfon at a concentration of $0.5-0.75$ ppm for $24 \mathrm{~h}$ is recommended by Chinabut (2002). Emamectin benzoate, which is very effective against crustacean parasites, is also being used to treat isopods in freshwater areas of Andhra Pradesh at a dose rate of $300-400 \mathrm{mg} / \mathrm{kg}$ feed for $3-5$ days, despite the fact that no scientific data is available regarding this treatmentve. However, unregulated use of such chemicals can have adverse effect on fish and environment (Wang et al. 2011). Rejeena et al (2021) has suggested that the usage of bacterial consortium with high chitinase, protease, lipase and urease activity, can be an effective biological control for A. typus infestion in fishes. Another method of biological control is to use plant extracts and introduction of predators like crabs (Shah et al. 2017).

In the face of global warming and fluctuating environmental changes, incidences of parasite infestations on fish are expected to become more frequent. Further studies are needed for finding effective control measures for parasites and for responsible chemical use for the safety of animals and environment, the sustainability of commercial aquaculture production and also for the human wellbeing.

\section{Declarations}




\section{Acknowledgement}

We are grateful to KUFOS, Kerala, India for their facilities extended for carrying out the study in the department of AAHM.

\section{Funding}

This work is supported by grants from NSPAAD coordinated by NBFGR, Government of India.

\section{Author contribution}

RCG and SG were responsible for data and sample collection, KS and SG were involved with the analysis, results interpretation and drafting of the manuscript. GI in critical revisions and editing of manuscript. As Principal Investigator of the project, DP was responsible for planning of the study, analysis and interpretation of results, critical evaluation and editing of the manuscript.

\section{Availability of data and material}

Author declare that there are no objections in the data availability and materials

\section{Conflicts of interest}

None.

\section{References}

1. Abowei JFN, Ezekiel EN (2011) A Review of Acanthocephala, Leeches Parasite crustaceans and some other parasites of Miscellaneous Taxa Infections in African Fish. International Animal and Veterinary Advances 3: 340-348

2. Anand Kumar A, Rameshkumar G, Ravichandran S, Nagarajan R, Prabakaran K, Ramesh M (2017) Distribution of isopod parasites in commercially important marine fishes of the Miri coast, East Malaysia. J Parasit Dis 41(1):55-61. http://doi.org.10.1007/s12639-016-0749-6

3. Andre MA, Marina GL, Geza TRS, RMT, Flavia SL, Luiz ERT, Claudia MM, Rubens RM, Veronica LSJ (2019) Occurrence of Isopods in Two Species of Snappers (Lutjanidae) from Northeast Brazil. Journal of Parasitology Research 1:1-8. https://doi.org/10.1155/2019/8176283

4. Aneesh PT, Sudha K, Helna AK, anilkumar G (2016b). Mothocya renardi (Bleeker, 1857) (Crustacea: Isopoda: Cymothoidae) parasitising Strongy/ura leiura (Bleeker) (Belonidae) of the Malabar coast of India: Redescription, occurrence and life-cycle. Syst Parasitol 93(6):583-599. http://doi:10.1007/s11230-016-9646-8.

5. Aydogdu A, Emre N, Emre Y (2015) Prevalence and intensity of parasitic helminths of thicklip grey mullet Chelon labrosus in hosts in Beymelek Lagoon Lake in Antalya, Turkey, according to season, 
host size, age, and sex of the host. Turkish journal of zoology 39: 643-651. http/doi:10.3906/zoo1403-55

6. Bruce NL (1983) Aegidae (Isopoda: Crustacea) from Australia with descriptions of three new species. J Nat Hist 17:757-788

7. Carrasson M, Cribb TH (2014) Benign effect of the fish parasitic isopod Ceratothoa cf. imbricata on Selenotoca multifasciata (Scatophagidae) from Australia. Dis Aqua Org 110: 173-180. http://doi.org/10.3354/dao02751

8. Charles Baillie, Rachel LW, Kerry AH, Nico JS, Stefano M, Robin MDB (2019) Hooked on you: shape of attachment structures in cymothoid isopods reflects parasitic strategy. BMC Evolutionary Biology 19:207. https://doi.org/10.1186/s12862-019-1533-x

9. Chinabut S (2002) A case study of isopod infestation in tilapia cage culture in Thailand. 201-202. In: JR Arthur,MJ Philllips, RP Subasinghe, MB reantaso, lh MacRae (ed) Primary aquatic animal health care in rural, small-scale, aquaculture development. FAO Fish. Tech. pap. No.406.

10. Collins C, Bresnan E, Brown L, Falconer L, Guilder J, Jones K, et al (2020). Impacts of climate change on aquaculture .MCCIP Sci. Rev. 2020: 482-520. Doi: 10.14465/2020.arc21.aqu

11. Eiras JC, Castro R, Crustacea. In: Eiras JC, Velloso AL; Pereira Jr J (Ed.). Parasitos de peixes marinhos da América do Sul. Rio Grande: Ed. da FURG, 2016. p. 285-359

12. Fernado CH, Hanek G (1973) Some parasitic copepod from Sri Lanka (Ceylon) with a synopsis of parasitic crustacea from Ceylonese fresh water fishes. Bull Fish Res Stn Sri Lanka (Ceylon) 24:63-67

13. Folmer O, Black M, Hoeh W, Lutz R, Vrijenjoek R (1994) DNA primers for amplification of mitochondrial cytochrome $\mathrm{c}$ oxidase subunit I from diverse metazoan invertibrates. Molecular Marine Biology and Biotechnology 3(5): 294-299

14. Gloria W, Ugbomeh AP, Gabriel UU (2019) Determination prevalence of cymothoid parasite fish families in Iwofe (Port Harcourt) Rivers state. African Journal of Biological Sciences 1 (4): 58-67. https://doi.org/10.33472/AFJBS.1.4.2019.58-67

15. Hadfield KA, Tuttle LJ, Smit NJ (2017) Elthusa winstoni sp. n. (Isopoda, Cymothoidae), a new fish parasitic isopod from Hawaii. ZooKeys 661: 125-135. http://doi.org/10.3897/zookeys.661.11251

16. Hanzelova V and Zintan R (1985) Epizootiological importance of the concurrent monogenean invasion in the carp. Helminthologia 22: 277-283.

17. Heckmann R (2003) Other ectoparasites infesting fish; copepods, branchiurans, isopods, mites and bivalves. Aquaculture Magazine, Nov/Dec pp: 1-6.

18. Ho J, Tonguthai K (1992) Flabelliferan isopods (Crustacea) parasitic on freshwater fishes of Thailand. Syst Parasitol 21: 203-210

19. Kabata Z (1985) Parasites and diseases of cultured in the tropics. Taylor \& francis Ltd.

20. Kaur P, Shrivastav (2014) Histological effect of monogenean parasites on gills of freshwater carps. European journal of biotechnology and bioscience 2: 50-53. 
21. Lima FS, Casali GP, Takemoto RM. Crustacea. In: Pavanelli, G C, Takemoto RM, Eiras JC. (Org.). Parasitologia de peixes de água doce do Brasil. Maringá: Eduem, 2013. p. 371-397.

22. Lopez NC (2001) Parasitic crustaceans in fishes from some Philippine lakes. In: Santiago CB, CuvinAralar ML Basiao ZU (ed) Conservation and Ecological management of Philippine Lakes in relation to fisheries and aquaculture, pp 75-79

23. Margolis L, Esch GW, Holmes JC, Kuris AM, Schad GA (1982) The use of ecological terms in parasitology (report of an ad hoc Committee of the American Society of Parasitologists) J Parasitol 68:131-133. https://doi.org/10.2307/3281335

24. Marcogliese, DJ (2008) The impact of climate change on the parasites and infectious disease of aquatic animals Rev. Sci. Tech.Off. Int. Epiz 27:467-484. Doi: 10.20506/rst.27.2.1820

25. Marcogliese, DJ (2016) The distribution and abundance of parasites in aquatic ecosystems in a changing climate: More than just temperature Integrative and Comparative Biology pp.1-9. doi: 10.1093/icb/icw036

26. Maula S, Hasimuna OJ, Haambiya LH, Monde C, Musuka CG, Makorwa TH, Munganga BP, Phiri KJ, Nsekanabo JD (2021) Climate change effects on aquaculture production: sustainability implications, mitigation and adoptations. Fron .Sustain. Food Syst 5: 609097. http://doi:10.3389/fsufs.2021.609097

27. Meik JM, Lawing AM (2008) Elevation gradients and lizard assemblage structure in the Bonneville basin, western USA Journal of Arid environments 72: 1193-1201

28. Misganaw K, Getu A (2016) Review on Major parasitic crustaceans in fish. Fisheries and aquaculture journal 7: 175. http://doi.org/10.4172/2150-3508.1000175

29. Nair AG (1980) Biology of the tropical isopods Porcellio laevis Latreille and Alitropus typus M Edwards. Dissertation, University of Kerala. http:/hdl.handle.net/10603/163946

30. Nair GA, Nair NB (1983) Effect of infestation with the isopod, Alitropus typus M. Edwards (Crustacea: Flabellifera: Aegidae) on the haematological parameters of the host fish, Channa striatus (Bloch). Aquaculture 30:11-19.

31. Ojwala Ra, Otachi EO, Kitaka NK (2018) Effect of water quality on the parasite assemblages infecting Nile tilapia in selected fish farms in Nakuru County, Kenya. Parasitology research 117 (11): 34593471. http://doi.org/10.1007/s00436-018-6042-0

32. Oommen MA, Shnaker K (2005) Elevarional species richness pattterns emerge from multiple local mechanisms in Himalayan wood plants Ecology 86: 3039-3047.

33. Peninal S, Rathna GS, Elavarasi A, Lalaiselvam M (2014) First report on the recods of parasitic infection in the Moray eel (Thyrsoidea macrura) along the Prangipettai coastal waters (Southeast coaast of India). J Parasit Dis 38:273-276. http://doi.org/10.1007/s12639-012-0227-8

34. Rajeena KB, Vineethaa VP, Devika Pillai (2021) Formulation of an exoskeleton degrading bacterial consortium from seafood processing effluent for the biocontrol of crustacean parasite Alitropus typus. Veterinary Parasitology 290: 109348. https://doi.org/10.1016/j.vetpar.2021.109348 
35. Rajkumar M, Perumal P, Trilles JP (2005) Cymothoa indica (Crustacea, Isopoda, Cymothoidae) parasitizes the cultured larvae of the Asian sea bass Lates calcalifer under laboratory conditions. Dis Aquat Organ 66: 87-90. http://doi.org/10.3354/dao066087

36. Rajkumar M, Vasagam KPK, Perumal P, Trilles JP (2005a) First record of Cymothoa indica (Crustacea, Isopoda, Cymothoidae) infecting the cultured catfish Mystus gulio in India. Dis. Aquat. Org 65: 269-272.

37. Rameshkumar G, Ravichandran S (2014) Problems caused by isopod parasites in commercial fishes. $J$ parasit Dis 38(1): 138-141.

38. Ravichandran S (2007) Infestation of isopod parasite Lironeca puhi in slender needle fish Strongy/ura leiura. Research journal in Parasitology 2: 87-93. http://doi.org/10.3923/jp.2007.87.93

39. Rivichandran S, Rameshkumar G, Kumarave K (2009) Variation in the Morphological Features of Isopod Fish Parasites. World Journal of Fish and Marine Sciences 1: 137-140.

40. Rivichandran S, Rameshkumar G, Balasubramanian T (2010) Infestation of isopod parasites in commercial marine fishes. J Parasit Dis 34: 97-98. http://doi.org/10.1007/s12639-010-0014-3

41. Rutkayova J, Vacha F, Marsalek M, Benes K, Civisova H, Horka P, et al (2017). Fish stock losses due to extreme floods-findings from pond-based aquaculture in the Czech Republic J. Food. Risk. Manage 11:351-359. Doi:10.1111/jfr3.12332.

42. Samira P, Esra U, Peyman Y, Sayed MS,Danial K, Masoud N, Alinaghi M, Kheirollah Y (2018) A simplfied and optimized protocol for total DNA extraction from insect species:applicable for stdying genetic diversity and PCR- based specimen identification via partial amplification of cytochrome oxidase I (COI) gene. Cellular and Molecular Biology 62 (12) 22-25.

http://doi.org/10.14715/cmb/2018.64.12.5

43. Samn A, Karima MM, Zeina A, Kkalaf AHMM (2014) First occurrence of Nerocila bivittata: parasitic isopods (skin shedders) on Lithognathus mormyrus (Osteichthyes, Sparidae) from Abu Qir Bay, Alexandria,Egypt. Journal of American Science 10(7): 171-179.

44. Santos D, Melo MRS, Mendes DCS, Rocha IK, Silva JPL, Cantanhede SM, Meletti PC (2014) Histological changes in gills of two fish species as indicators of water quality in Jansen lagoon (Sao Luis, Maranhao state, Brazil). International journal of environmental research and public health 11:12927-12937. http://doi.org/10.3390/ijerph111212927

45. Shah SAA, Asharf A, Qureshi NA (2017) Morphological characterization and biological control of Alitropus typus (Isopoda:Aegidae). Entomol. Res. http://doi.org/10.1111/1748-5967.12231

46. Short EE, Caminade C, Thomas BN (2017) Climate change contribution to the emergence or reemergence of parasitic diseases Infectious diseases research and treatment 10:1-7. doi. $10.1177 / 1178633617732296$

47. Wang Y, Wu Z, Wang G, Wang F, Liu Y, LiF, Han J (2011) In vivo anthelmintic activity of bruceine A and bruceine $D$ from Brucea javanica against Dactylogyrus intermedius (Monogenean) in goldfish (Carassius auratus). Vet Parasitol 177:127-33. http://doi.org/10.1016/j.vetpar.2010.11.040 
48. Watchariya P, Apiruedee S (2020) New Records of Fish Parasitic lopods (Crustacea: Isopoda) from the Gulf of Thailand. Animals 10, 2298. http://doi.org/10.3390/ani10122298

\section{Figures}
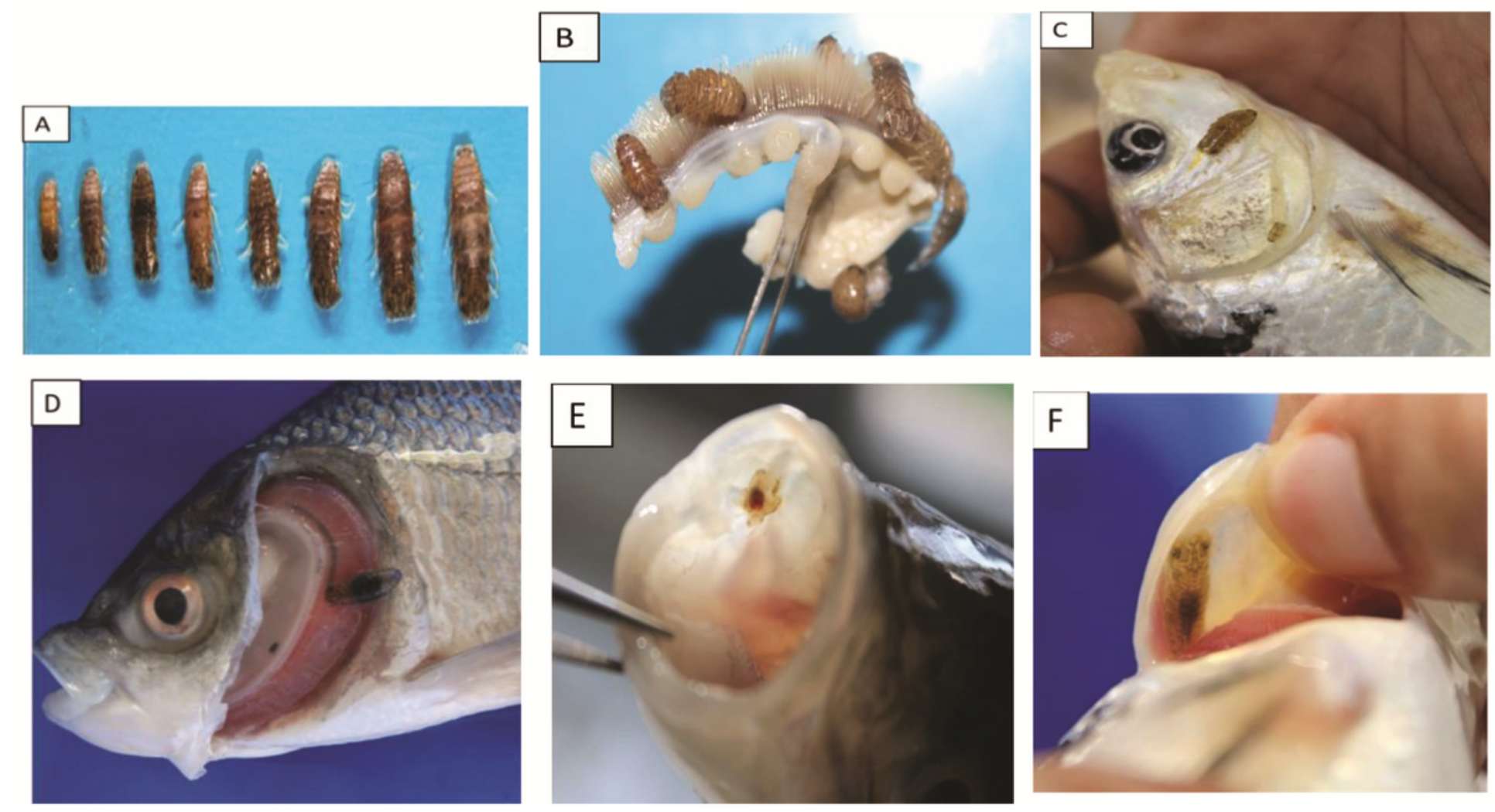

\section{Figure 1}

A. typus infestation on different fish hosts and the sites of infestation. A. Specimens collected from C. striata, B. Intensity of infestation on the gills of C. striata, C. On the head region of C. carpio, D. Gills of C. catla. E. Buccal cavity of Cyprinus carpio, F. Opercular chamber of C. carpio 


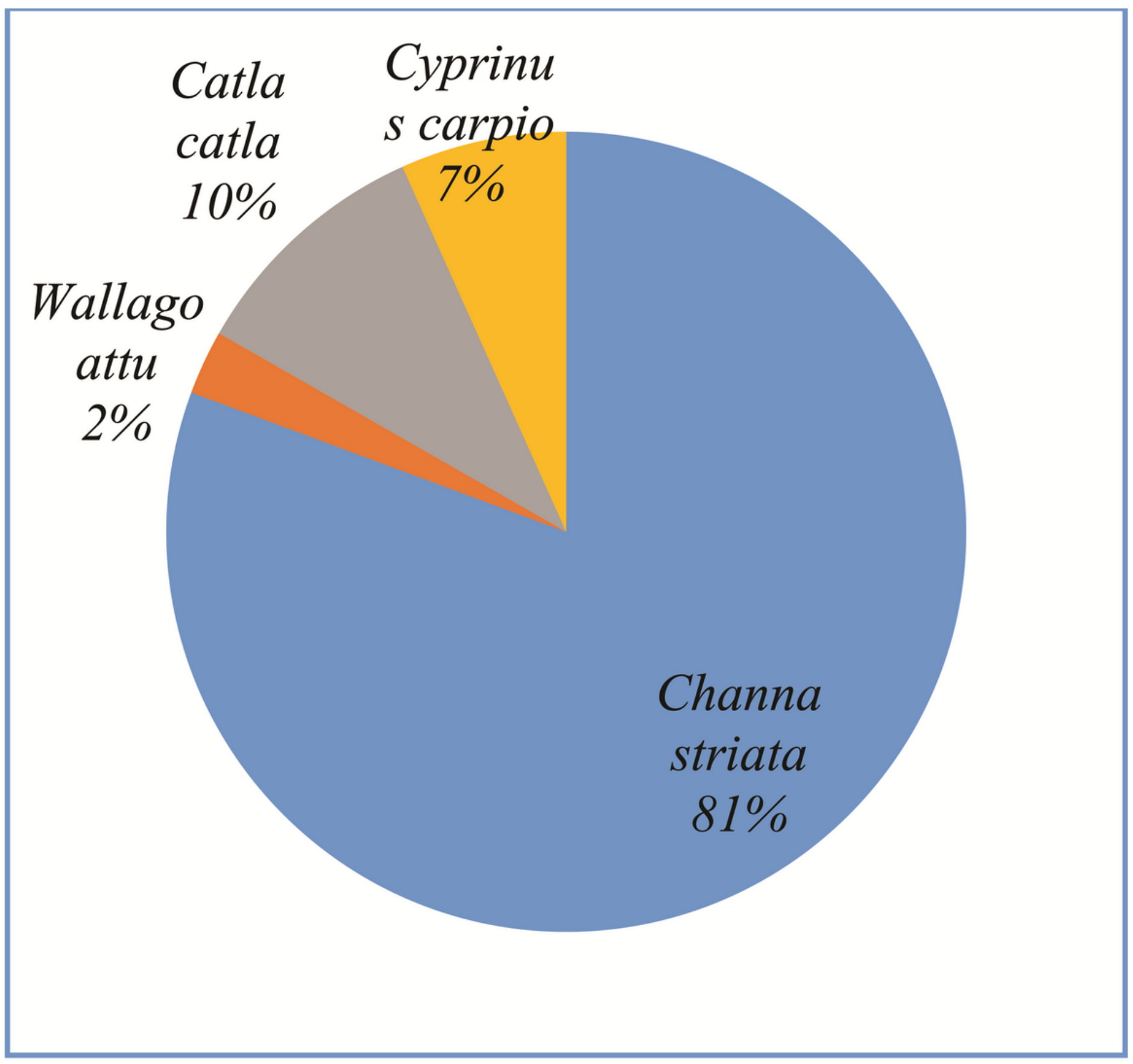

Figure 2

A. typus infestation in different hosts 

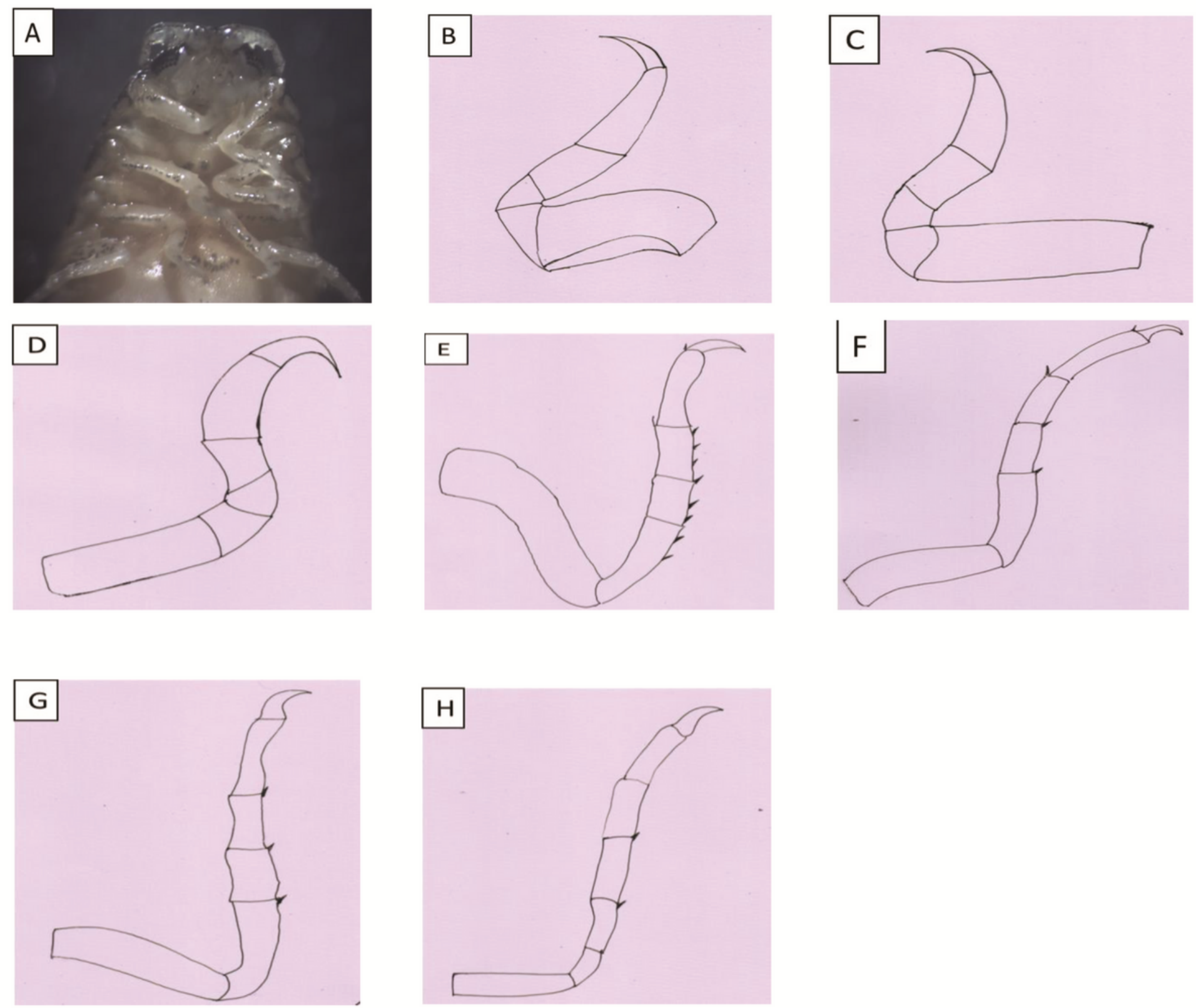

\section{Figure 3}

Morphology of the pereopods of A. typus. A. Ventral view of parasite, $\mathrm{B}$ to $\mathrm{H}$ indicates 1-7 pereopods 

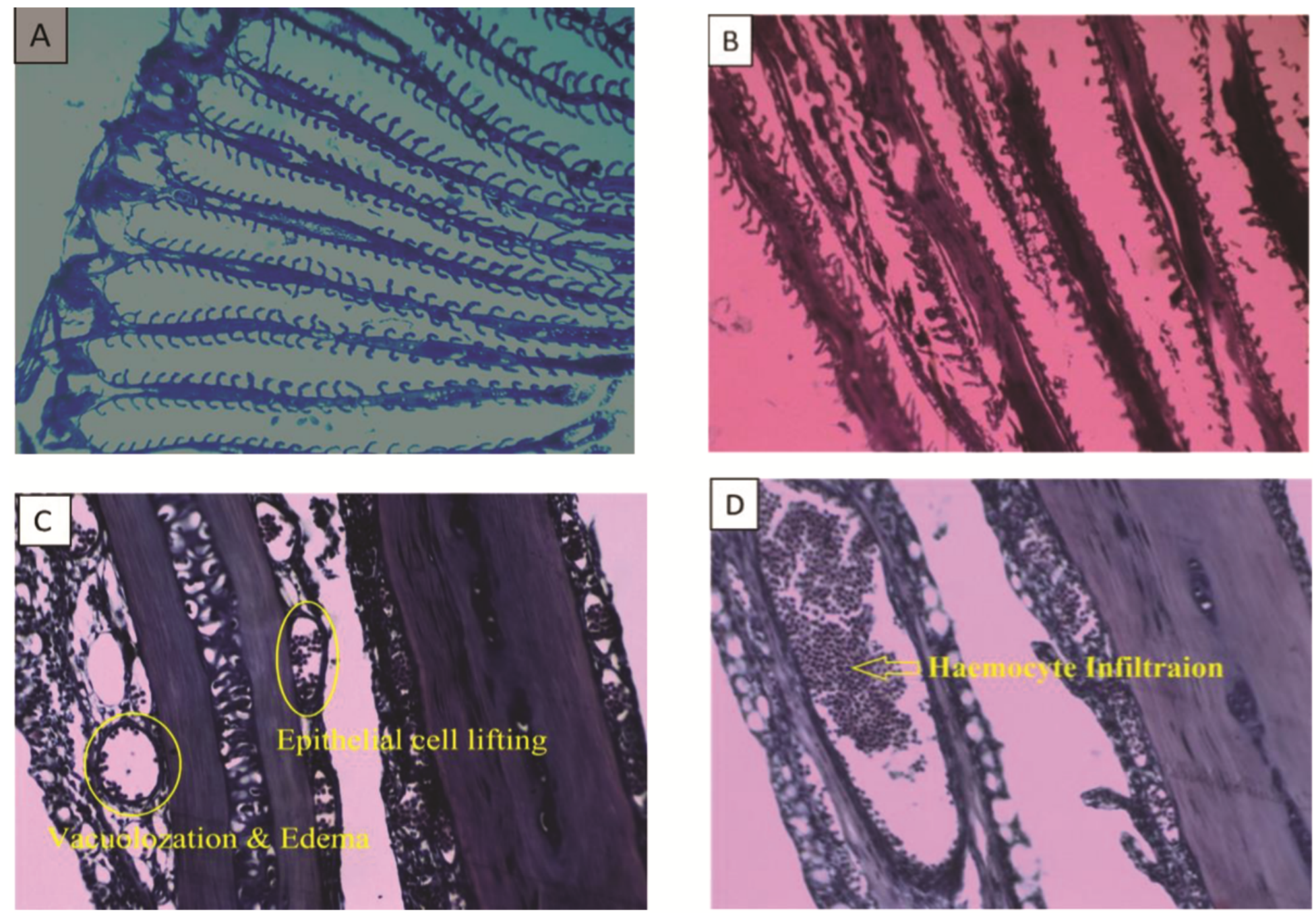

Figure 4

Histopathological changes of gill tissues of Channa striata: A. Section through the gills of a normal fish, showing the normal arrangement of secondary lamellae $(\mathrm{H}+\mathrm{E} \times 100)$, B. sections of parasite infested gills showing the rupture of the primary and secondary lamellae $(\mathrm{H}+\mathrm{E} \times 100), \mathrm{C}$. Vacuolization, edema and epithelial lifting $(H+E \times 400)$, D. Haemocytic infiltration (H+Ex400) 


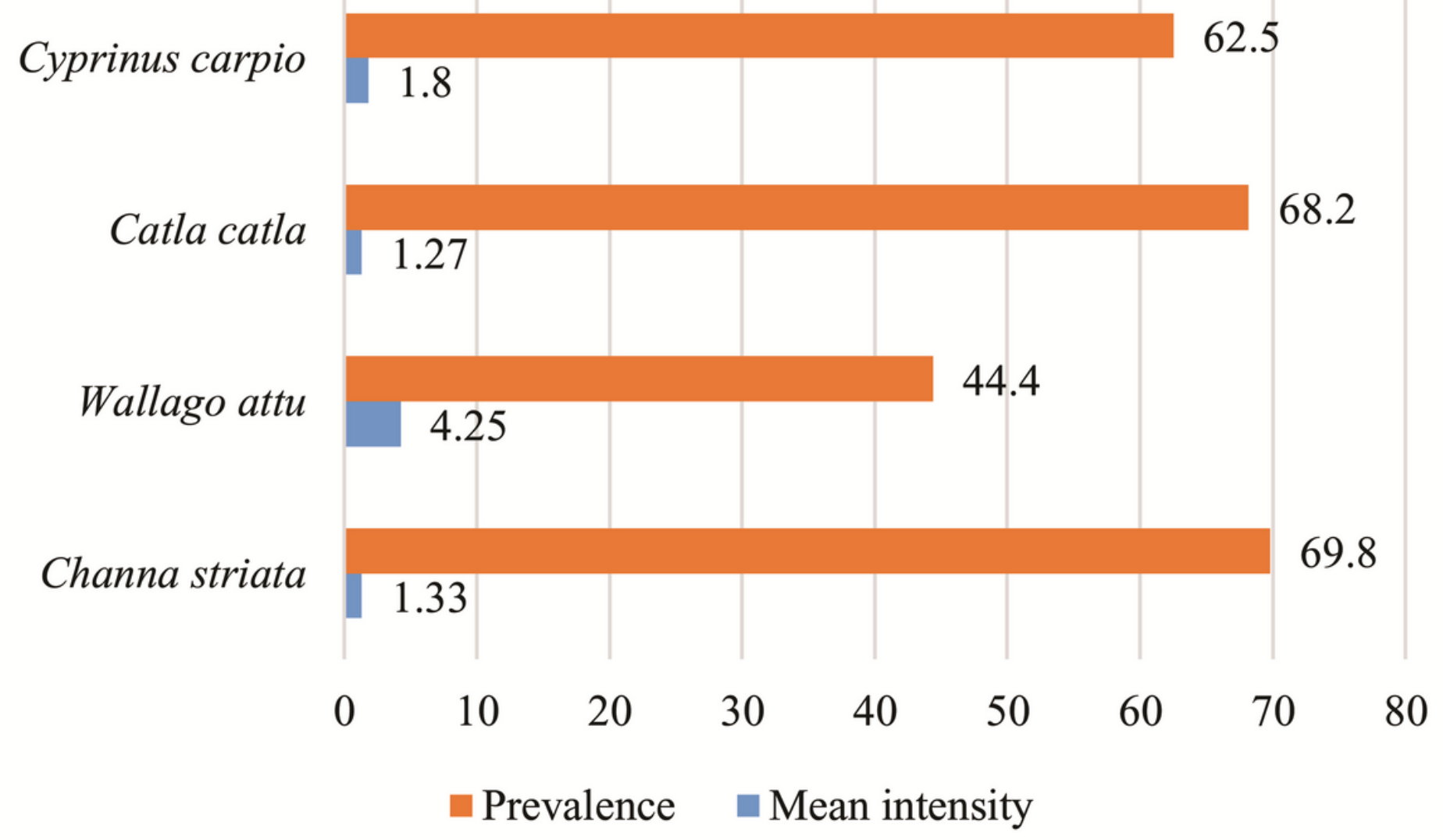

Figure 5

Mean intensity and prevalence of A. typus infestation in different hosts 


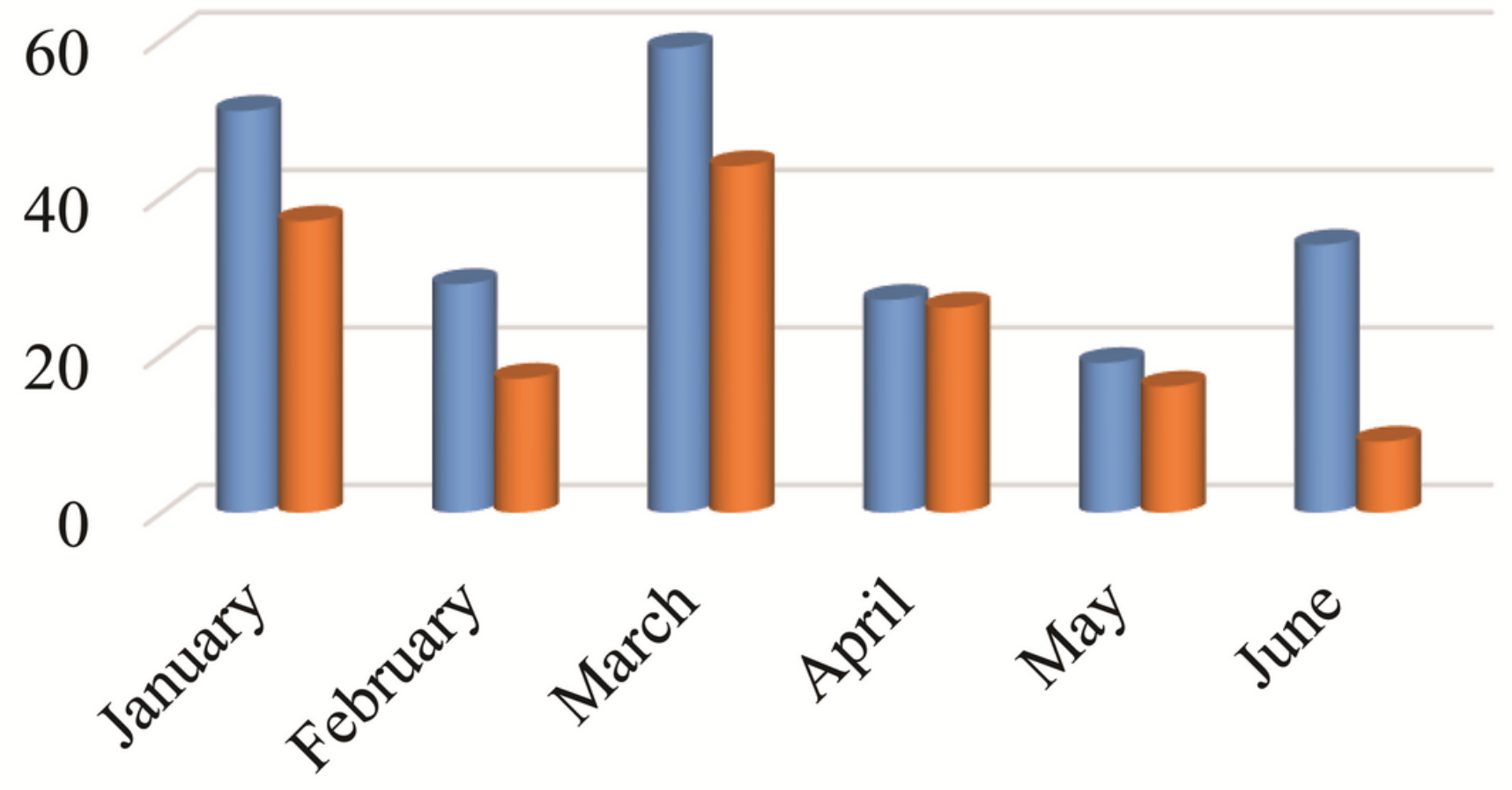

\section{- Total no. of fishes examined \\ Total no. of fishes infested}

\section{Figure 6}

Monthly variation in infestation of A. typus from January to June

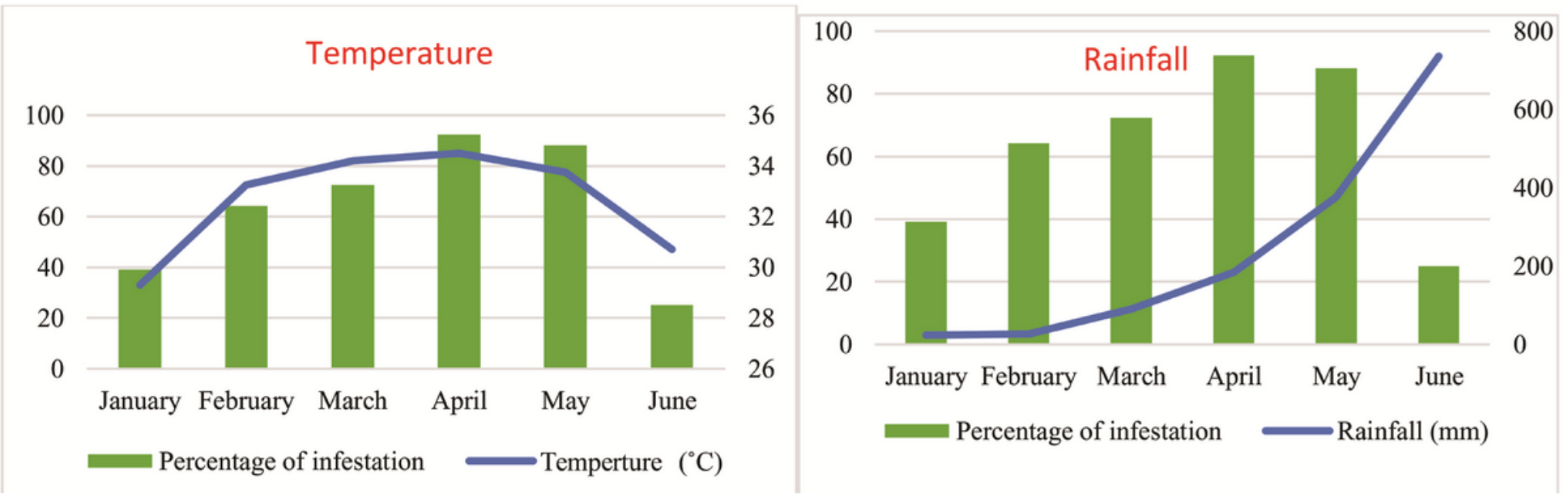

Figure 7

Changes in percentage of infestation with changes in temperature and rainfall 